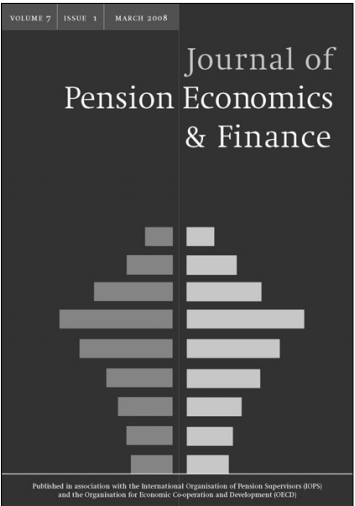

Journal of Pension Economics and Finance

is available online at:

journals.cambridge.org/pef

To subscribe contact

Customer Services

\section{in Cambridge:}

Phone +44 (0)1223 326070

Fax +44(0)1223 325150

Email journals@cambridge.org

\section{in New York:}

Phone (845) 3537500

Fax (845) 3534141

Email

subscriptions_newyork@cambridge.org
Journal of

Pension

Economics and

Finance

\title{
Editors
}

Steven Haberman, Cass Business School, City University, UK Moshe Milevsky, York University, Canada

J. Michael Orszag, Watson Wyatt, UK

The Journal of Pension Economics and Finance (JPEF) is the only academic journal focusing on the economics and finance of pensions and retirement income. The ageing population, together with the shrinking workforce, heralds a growing pensions crisis, which has become a key public policy issue in developed countries and elsewhere. JPEF provides a valuable and influential forum for international debate in this area.

Price information is available at: journals.cambridge.org/pef

\section{Free email alerts}

Keep up-to-date with new material sign up at journals.cambridge.org/register

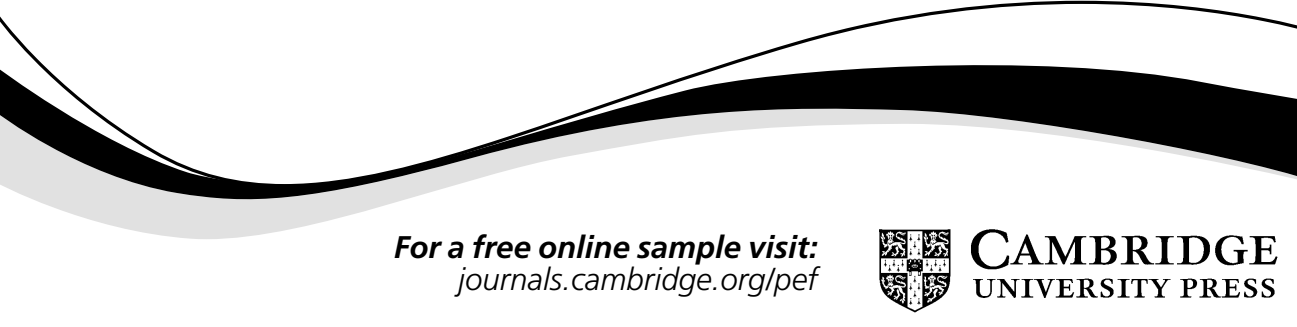




\section{CAMBRIDGE}

\section{NEW AND NOTEWORTHY}

\section{Violence and Social Orders}

A Conceptual Framework for Interpreting Recorded Human History Douglass C. North, John Joseph Wallis, and Barry R. Weingast

\$30.00: Hb: 978-0-521-76173-4: 328 pp.

\section{The Romantic Economist} Imagination in Economics Richard Bronk \$85.00: Hb: 978-0-521-51384-5: 400 pp. \$27.99: Pb: 978-0-521-73515-5

\begin{tabular}{l}
\multicolumn{1}{|c|}{ HISTORICAL PERSPECTIVES } \\
ON MODERN ECONOMICS \\
\hline The Intellectual Foundations of \\
Alfred Marshall's Economic Science \\
A Rounded Globe of Knowledge \\
Simon J. Cook \\
\$90.00: Hb: $978-0-521-76008-9: 376 \mathrm{pp}$. \\
The Economics of Karl Marx \\
Analysis and Application \\
Samuel Hollander \\
\$130.00: Hb: $978-0-521-79078-9: 550 \mathrm{pp}$. \\
\$65.00: Pb: $978-0-521-79399-5$
\end{tabular}

Markets, Money and Capital Hicksian Economics for the Twenty-First Century Edited by Roberto Scazzieri, Amartya Sen, and Stefano Zamagni \$99.00: Hb: 978-0-521-87321-5: 466 pp.
Theory of Decision under Uncertainty Itzhak Gilboa

Econometric Society Monographs \$85.00: Hb: 978-0-521-51732-4: 224 pp. \$29.99: Pb: 978-0-521-74123-1

\section{The Methodology of Positive Economics Edited by Uskali Maki \$130.00: Hb: 978-0-521-86701-6: 400 pp.} \$48.00: Pb: 978-0-521-68686-0

\section{Humanism in Business}

Edited by Heiko Spitzeck, Michael Pirson, Wolfgang Amann, Shiban Khan, and Ernst von Kimakowitz \$110.00: Hb: 978-0-521-89893-5: 472 pp. \$39.99: Pb: 978-0-521-72762-4

\section{The Theory of the Firm} Microeconomics with Endogenous Entrepreneurs, Firms, Markets, and Organizations Daniel F. Spulber \$120.00: Hb: 978-0-521-51738-6: 544 pp. \$45.00: Pb: 978-0-521-73660-2

\section{Theoretical Foundations} of Law and Economics Edited by Mark D. White \$85.00: Hb: 978-0-521-88955-1: 304 pp.
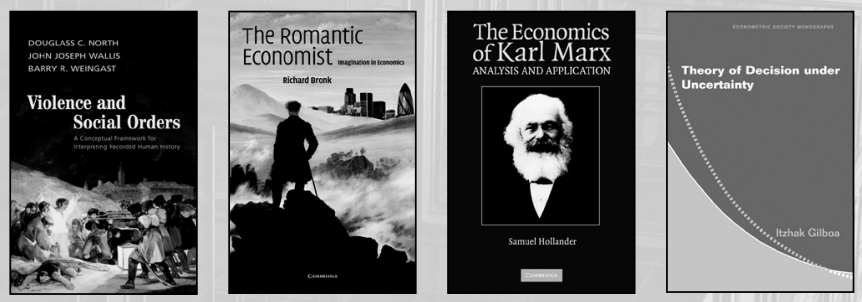

Prices subject to change.

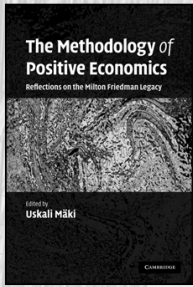


All rights reserved. No part of this publication may be reproduced, in any form or by any means, electronic, photocopying or otherwise, without permission in writing from Cambridge University Press. Photocopying information for users in the USA:

The Item-Fee Code for this publication (0266-2671/2009 \$12.00) indicates that copying for internal or personal use beyond that permitted by Sec. 107 or 108 of the U.S. Copyright Law is authorized for users duly registered with the Copyright Clearance Center (CCC) Transaction Reporting Service, provided that the appropriate remittance of $\$ 12.00$ per article is paid directly to: CCC, 222 Rosewood Drive, Danvers, MA org23. Specific written permission must be obtained from Cambridge University Press for all other copying. Contact the I5I Tearsheet Service, 350r Market Street, Philadelphia, PA I9I04, for single copies of separate articles.

This journal issue has been printed on FSC-certified paper and cover board. FSC is an independent, non-governmental, not-for-profit organization established to promote the responsible management of the world's forests. Please see www.fsc.org for information.

(C) 2009 Cambridge University Press

CAMBRIDGE UNIVERSITY PRESS

The Edinburgh Building, Shaftesbury Road, Cambridge CB2 8RU, United Kingdom 32 Avenue of the Americas, New York, NY Ioor3-2473, USA

477 Williamstown Road, Port Melbourne, VIC 3207, Australia

Ruiz de Alarcón I3, 28or4 Madrid, Spain

Dock House, The Waterfront, Cape Town 8oor, South Africa

Printed in the United Kingdom at the University Press, Cambridge 


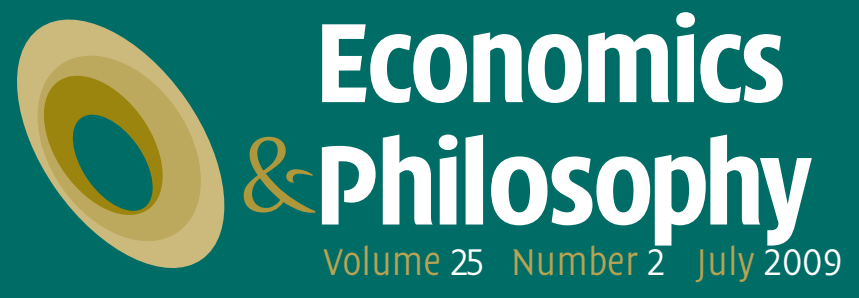

\section{WALTER BOSSERT AND KOTARO SUZUMURA \\ JOSEPH B. KADANE AND GAiA BELLONE \\ FRANK HINDRIKS}

BENEDETTO GUI

JULIE A. NELSON

LUIGINO BRUNI AND

ROBERT SUGDEN

DAVID TEIRA

Kevin D. Hoover

ARIS SPANOS

JULIAN REISS

DANiEL M. HAYBRon

CATERINA MARCHIONNI

PierRe SALMON

Katie Steele

\section{Articles}

External Norms and Rationality of Choice I39

De Finetti on Risk Aversion 153

Corporate Responsibility and Judgment Aggregation I6I

\section{Discussion}

On Mutual Benefit and Sacrifice: A Comment on Bruni and Sugden's 'Fraternity' 179

A Response to Bruni and Sugden 187

Fraternity, Intrinsic Motivation and Sacrifice: A Reply to Gui and Nelson 195

\section{Reviews}

Reviews symposium

Measurement and value judgments in economics: on Error in Economics. Towards a More Evidence-Based Methodology, by Julian Reiss 199

How can economics be an inductive science?: on Error in Economics. Towards a More Evidence-Based Methodology, by Julian Reiss 202

Error in economics and the error statistical approach: on Error in Economics. Towards a More Evidence-Based Methodology, by Julian Reiss 206

Rejoinder: on Error in Economics. Towards a More Evidence-Based Methodology, by Julian Reiss 210

\section{Other reviews}

Economics and Happiness: Framing the Analysis, edited by Luigino Bruni and Pier Luigi Porta 217

Popper and Economic Methodology. Contemporary Challenges, edited by Thomas A. Boylan and Paschal F. O'Gorman 223

Explaining Social Behavior: More Nuts and Bolts for the Social Sciences, by Jon Elster 229

Preference and Information, by Dan Egonsson 236 Contributors 243
Cambridge Journals Online For further information about this journal please go to the journal website at: journals.cambridge.org/eap

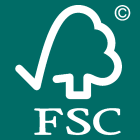

